16. Pataryas, H. A., and Christodoulou, C.: Alterations in human organ alkaline phosphatases during foetal development. Human Hered., 20: 420 (1970).

17. Posen, S.: Alkaline phosphatase. Ann. Intern. Med., 67: 183 (1967).

18. Rathbun, J. C.: Hypophosphatasia, a new developmental anomaly. Amer. J. Dis. Child., 75: 822 (1948)

19. Riley, P. A., and Sperman, R. I. C.: Vitamin A-induced synthesis of alkaline phosphatase. Science, 160: 1006 (1968).

20. Schlamowitz, M., and Bodansky, O.: Tissue sources of human serum alkaline phosphatase, as determined by immunochemical procedures. J. Biol. Chem., 234: 1433 (1959).

21. Teree, T. M., and Klein, L.: Hypophosphatasia: Clinical and metabolic studies. J. Pediat., 72: 41 (1968)

22. Warshaw, J. G., Littlefield, J. W., Fishman, W. H., Inglis, N. R., and Stolbach, L. L.: Serum alkaline phosphatase in hypophosphatasia. J. Clin. Invest., 50: 2137 (1971).

23. Weissman, G.: Labilization and stabilization of lysosomes. Fed. Proc., 23: 1038 (1964)

24. Yaffe, S. J., Levy, G., Matauzawa, T., and Baliah, T.: Enhancement of glucuronide-conjugating capacity in a hyperbilirubinemic infant due to apparent enzyme induction by phenobarbital. New Engl. J. Med., 275: 1461 (1966).

25. Zinkham, W. H., Blanco, A., and Kupchyk, L.: Isozymes: Biological and clinical significance. Pediatrics, 37: 120 (1966).
26. Cellogel, Chemetron, Milan, Italy; available through Kalex Scientific Co., Manhasset, N.Y.

27. The authors are indebted to Drs. M. Crea, L. Schiff, and D. Weinstein for the opportunity to study the patients; to Dr. H. B. Robinson, Department of Pathology, Children's Hospital of Buffalo, for providing us with the autopsy specimens for alkaline phosphatase studies; to Dr. I. A. Schafer, Department of Pediatrics, Cleveland Metropolitan General Hospital, for the determination of urinary mucopolysaccharides; to Dr. L. M. Sherwood, Beth Israel Hospital, Boston for serum parathormone determinations and to the following investigators of the Children's Hospital of Buffalo for their help in the clinical evaluation of the patients: L. G. MacDougall, D. Kerr-Grant, P. L. Ogra, J. Rahill, W. Georgi, D. Klein, and R. Munschauer. We wish to express our gratitude to the staff of the Clinical Research Center for the care the patients received during their prolonged hospitalizations.

28. This research was supported in part by Public Health Service Grants FR-05493, FR-77, HD-06321: Department of Health, Education and Welfare Maternal and Child Health Services, Project 417; and a grant from the United Health Foundation of Western New York.

29. Requests for reprints should be addressed to: R. Gorodischer, M.D., KupatHolim, P.O.B. 151, The Soroka Medical Center, Beer-Sheba (Israel).

30. Accepted for publication January 28, 1976.
Aorta

blood flow

blood pressure oxygen

umbilical artery catheter

\title{
Effect of Umbilical Artery Catheters on Blood Flow and Oxygen Supply to Extremities
}

\author{
ROBERT F. HUXTABLE, (13) KENNETH G. PROCTOR, AND ANTHONY V. BERAN \\ Department of Pediatrics, College of Medicine, University of California, Irvine, California, USA
}

\section{Extract}

The effect of catheter placement in the abdominal aorta on the blood flow and oxygenation of lower extremities was evaluated in $\mathbf{3 0}$ New Zealand rabbits, weighing $0.55-3.5 \mathrm{~kg}$, by inserting 3.5 and 5.0 French polyvinyl chloride catheters, of the type commonly used for umbilical artery catheterization, through the femoral artery, advancing $15-20 \mathrm{~cm}$, and leaving in place for $10-30 \mathrm{~min}$. Arterial blood pressure (BP), common iliac artery blood flow (BF), gracilis muscle tissue oxygen availability $\left(\mathrm{O}_{2} \mathrm{a}\right)$, and subcutaneous temperature $(T)$ in the foot were continuously monitored before and during catheter placement and after withdrawal. There were no changes in the physiologic variables measured in the contralateral leg when the catheter remained below the aortic bifurcation; however, when the catheter was advanced $15-20 \mathrm{~cm}$ into the abdominal aorta, a decrease in lower extremity $\mathrm{BF}, \mathrm{O}_{2} \mathrm{a}$, and $\mathrm{T}$ occurred. Because the length of catheter insertion was maintained constant in each animal, the decreases in $\mathrm{BF}, \mathrm{O}_{2} \mathrm{a}$, and $\mathrm{T}$ are related to the relative dimensions of the vessel and the catheter. The ratio of catheter to vessel diameter, in addition to the site of catheter placement, should be considered during the clinical application of arterial catheters. Reduction in blood flow could be detected by continuous differential monitoring of core and extremity temperature or extremity muscle oxygen availability.

\section{Speculation}

Placement of catheters in the aortas of animals of physical sizes comparable to those of newborn infants may produce an appreciable obstruction to aortic flow. Until a suitable noninvasive method of assessing oxygenation in newborns is available, umbilical artery catheters should be of the smallest possible outside diameter and placed below the bifurcation of the abdominal aorta.

The patency of the umbilical vessels at birth allows long term catheterization. In 1959, James (5) reported the use of an umbilical artery catheter to obtain repeated samples for blood gas and $\mathrm{pH}$ analysis. Since that time, catheterization of umbilical vessels has become a routine procedure in the management of diseased neonates. Various authors (7) have suggested catheter placement in: (l) the abdominal aorta, distal to the renal and inferior mesenteric arteries and proximal to the aortic bifurcation (6), (2) the thoracic aorta, distal to the ductus arteriosus (6), or (3) the iliac artery, distal to the aortic bifurcation $(1,11)$. Although this procedure facilitates the care of sick infants, especially those requiring respiratory support and fluid maintenance, it may lead to serious complications including thrombosis, infection, vessel perforation, extremity blanching, and visceral necrosis $(7,8)$.

A catheter placed in an artery produces a partial acute mechanical obstruction equivalent to coarctation of the aorta, and measurement of this effect has not been previously reported. Poiseuille's law was used as the theoretical rationale for this study.

$$
\dot{\mathrm{Q}}=\frac{\pi\left(\mathrm{P}_{2}-\mathrm{P}_{1}\right)}{8 \lambda \mathrm{L}}\left[\mathrm{r}_{2}^{4}-\mathrm{r}_{1}^{4}-\frac{\left(\mathrm{r}_{2}^{2}-\mathrm{r}_{1}^{2}\right)^{2}}{\ln \frac{\mathrm{r}_{2}}{\mathrm{r}_{1}}}\right]
$$


where $\dot{Q}=$ flow, $\lambda=$ viscosity, $\mathrm{L}=$ catheter length within the aorta, $\mathrm{P}_{1}=$ blood pressure at the proximal end of $\mathrm{L}, \mathrm{P}_{2}=$ blood pressure at the distal end of $\mathrm{L}, \mathrm{r}_{1}=$ catheter outside radius, and $\mathrm{r}_{2}=$ vessel inside radius. Streamline flow of a Newtonian fluid through an annular system is primarily effected by $\Delta r$, which is a fourth power variable. Although an in vivo situation differs from the ideal in vitro situation (non-Newtonian characteristics of blood, pulsatile rather than steady flow, elasticity of the outer wall, etc.), we speculated that because of the possibility of vasospasm, the greater viscosity of blood, and the turbulent rather than laminar flow through the annular space, the flow would be decreased even further than predicted.

The purpose of this study was to evaluate the effect of $r(3.5 \mathrm{~F}$ and $5.0 \mathrm{~F}$ catheters) on blood flow and oxygen supply to the extremities. In addition, new criteria which could detect the changes in oxygenation related to catheter complications have been sought.

\section{METHODS}

\section{EXPERIMENTAL PROCEDURE}

Male New Zealand rabbits were used in the study. Anesthesia was induced by injecting sodium pentobarbital $(25 \mathrm{mg} / \mathrm{kg})$ into an ear vein. The animal was placed on a heating blanket (Gorman Rupp) maintained at $39^{\circ}$. In 10 animals $(1.6-3.5 \mathrm{~kg})$, the right common iliac artery was surgically exposed intraperitoneally and a blood flow probe and an arterial occluder (2) were secured around the vessel. A needle thermistor was placed subcutaneously distal to the probe in the right foot. An oxygen electrode was implanted in the right gracilis muscle distal to the probe and proximal to the thermistor. An arterial catheter (3.5F or $5.0 \mathrm{~F})$ was then inserted into the left femoral artery, $3 \mathrm{~cm}$ from the bifurcation of the abdominal aorta (Fig. 1). After a 30-min stabilization period, control values for the physiologic variables measured were obtained.

The catheter was then advanced $15-20 \mathrm{~cm}$ and left in place for 10-30 min, or until zero $\mathrm{O}_{2}$ a level was reached. The catheter was then withdrawn to its $3-\mathrm{cm}$ mark. If the $3.5 \mathrm{~F}$ catheter produced a significant obstruction, as manifested by decreased $\mathrm{BF}$ or $\mathrm{O}_{2} \mathrm{a}$, the $5.0 \mathrm{~F}$ catheter was not used. Zero $\mathrm{O}_{2}$ a and $\mathrm{BF}$ levels were obtained by periodic occlusion of the vessel and at death. Catheter site and aortic diameter were verified by aortogram. In 20 additional

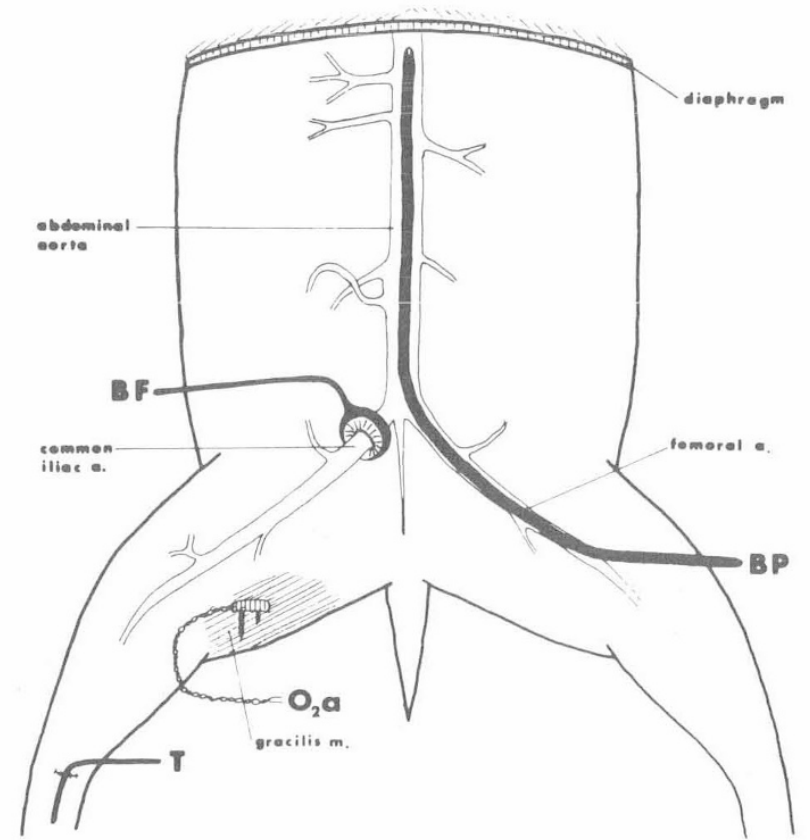

Fig. 1. Experimental design, sites of catheter, and sensor placement. animals ( 0.55 to $2.6 \mathrm{~kg})$ the above procedure was repeated, without placement of the blood flow probe, to eliminate possible vascular constriction by the probe.

\section{PHYSIOLOGIC VARIABLES}

BP was continuously monitored by a pressure transducer (Statham P23Db). T was measured by a thermistor (Yellow Springs, Telethermometer). BF was continuously monitored by an electromagnetic blood flow meter (IVM EMF 101). $\mathrm{O}_{2}$ a was continuously monitored polarographically (3) using a commercially available Hydron-coated gold cathode and an $\mathrm{Ag}-\mathrm{AgCl}$ skin surface anode (International Biophysics Corporation, Irvine, California). When voltage above the oxygen decomposition potential is applied to the cathode, the current produced is proportional to the amount of oxygen reduced. In the tissue, the amount of $\mathrm{O}_{2}$ reduced is proportional to the tissue $\mathrm{pO}_{2}$, which in turn is effected by total oxygen delivery, $\mathrm{O}_{2}$ release, and tissue metabolic rate. $\mathrm{BF}$ and $\mathrm{O}_{2}$ a are expressed as a percentage of control. All other variables were expressed in absolute values. Control values were obtained following stabilization time and prior to catheter advancement to the 15-20-cm mark. All dynamic variables were recorded on a chart recorder (Sanborn 358-100).

\section{RESULTS}

Aortograms revealed that the aortic diameter in these animals was $3-6 \mathrm{~mm}$.

The effect of a $3.5 \mathrm{~F}$ and a $5.0 \mathrm{~F}$ catheter on BP, BF, T, and $\mathrm{O}_{2} \mathrm{a}$ in a $2.7-\mathrm{kg}$ animal is shown in Figures 2 and 3 . The $3.5 \mathrm{~F}$ catheter advanced $15 \mathrm{~cm}$ (Fig. 2) had no effect on these variables. When the common iliac artery was occluded, a moderate decrease in $\mathrm{T}$ and a precipitous drop to the zero level in $\mathrm{BF}$ and $\mathrm{O}_{2}$ a occurred.

The $5.0 \mathrm{~F}$ catheter advanced $15 \mathrm{~cm}$ (Fig. 3) produced a $100 \%$ decrease in $\mathrm{BF}$ and $\mathrm{O}_{2}$ a, whereas $\mathrm{T}$ decreased only $1.2^{\circ}$ with no appreciable effect on BP. When the catheter was withdrawn to its 3 -cm mark, all variables returned to the control levels.

Table 1 shows mean and standard deviation changes for all the physiologic variables monitored in two weight groups of animals. In the weight group $1.6-2.3 \mathrm{~kg}, 3.5 \mathrm{~F}$ catheters produced only slight changes in $\mathrm{BP}$ and $\mathrm{T}$, but decreased $\mathrm{BF}$ to $67 \pm 44 \%$ and $\mathrm{O}_{2}$ a to 56 $\pm 50 \%$, which represented a significant change from control $(p<$ $0.025 ; t=2.530)$. Of nine determinations, four showed decreased $\mathrm{O}_{2} \mathrm{a}$ and $\mathrm{BF}$. However, in the heavier weight range of $2.6-3.5 \mathrm{~kg}$, $3.5 \mathrm{~F}$ catheters produced only small, insignificant changes in $\mathrm{O}_{2} \mathrm{a}$ and $\mathrm{BF}$ to $86 \pm 35 \%$ and $90 \pm 24 \%$, respectively. Of six determinations, only one showed a decrease in $\mathrm{O}_{2}$ a or $\mathrm{BF}$.

Of 15 determinations with the $5.0 \mathrm{~F}$ catheter, all showed marked decreases in both $\mathrm{O}_{2}$ a and $\mathrm{BF}$. In the weight range 1.6-2.3 kg, BP and $\mathrm{T}$ changed insignificantly, but $\mathrm{O}_{2}$ a decreased to $22 \pm 34 \%(p$ $<0.001 ; t=6.063)$, and BF decreased to $21 \pm 32 \%(p<0.001 ; t$ $=6.514)$. In the heavier weight range $(2.6-3.5 \mathrm{~kg}), \mathrm{O}_{2} \mathrm{a}$ and $\mathrm{BF}$ decreased to $31 \pm 27 \%(p<0.001 ; t=5.201)$ and $73 \pm 6 \%(p<$ $0.001 ; t=7.702)$, respectively.

Table 2 shows the changes in physiologic variables in four weight groups of animals without blood flow probe placement. In the weight range of $0.55-1.0 \mathrm{~kg}, 3.5 \mathrm{~F}$ catheters significantly increased BP from $92 \pm 4 / 67 \pm 7 \mathrm{~mm} \mathrm{Hg}$ to $113 \pm 22 / 88 \pm 8 \mathrm{~mm}$ $\mathrm{Hg}(p<0.01 ; t=3.776)$ and decreased $\mathrm{O}_{2}$ a to $36 \pm 42 \%$ of control $(p<0.025 ; t=3.034)$. Extremity temperature decreased moderately but insignificantly. Of five determinations, four showed decreased $\mathrm{O}_{2}$ a. However, in the range of $1.4-2.6 \mathrm{~kg}, 15$ determinations with the $3.5 \mathrm{~F}$ catheter showed no effect on $\mathrm{O}_{2} \mathrm{a}$, and only slight insignificant changes in BP and T. The difference in $\mathrm{O}_{2}$ a after $10 \mathrm{~min}$ in these two weight groups is significant $(p<$ $0.01 ; t=3.034$ ).

In the weight range of $0.55-1.5 \mathrm{~kg}, 5.0 \mathrm{~F}$ catheters decreased $\mathrm{O}_{2} \mathrm{a}$ precipitously to $1 \pm 1 \%$ within $10 \mathrm{~min}$, representing a significant change from control ( $p<0.001 ; t=149.015)$. Of six determinations, all showed large decreases in $\mathrm{O}_{2} \mathrm{a}$. However, in the 1.6-2.6 $\mathrm{kg}$ weight range, $\mathrm{O}_{2}$ a showed only slight decreases $(100 \%$ to $98 \pm$ 


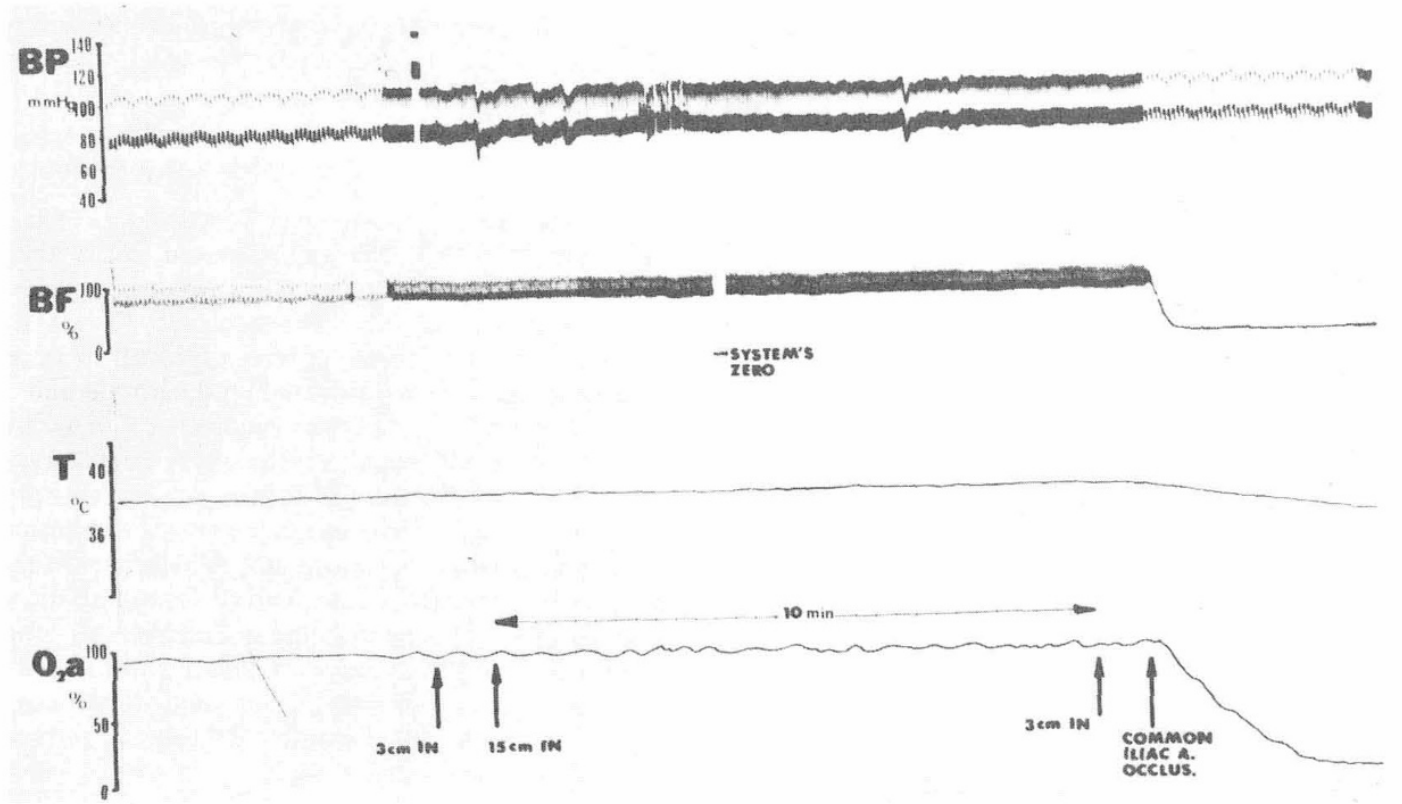

Fig. 2. Change in blood pressure $(B P)$, right common iliac artery blood flow $(B F)$, gracilis muscle tissue oxygen availability $\left(O_{2} a\right)$, and extremity temperature $(T)$ produced by advancement of $3.5 \mathrm{~F}$ catheter in $2.7-\mathrm{kg}$ animal. $3 \mathrm{~cm} \mathrm{IN}$ : catheter tip below bifurcation of the aorta; $15 \mathrm{~cm} I N$ : catheter advanced to 15 -cm mark.
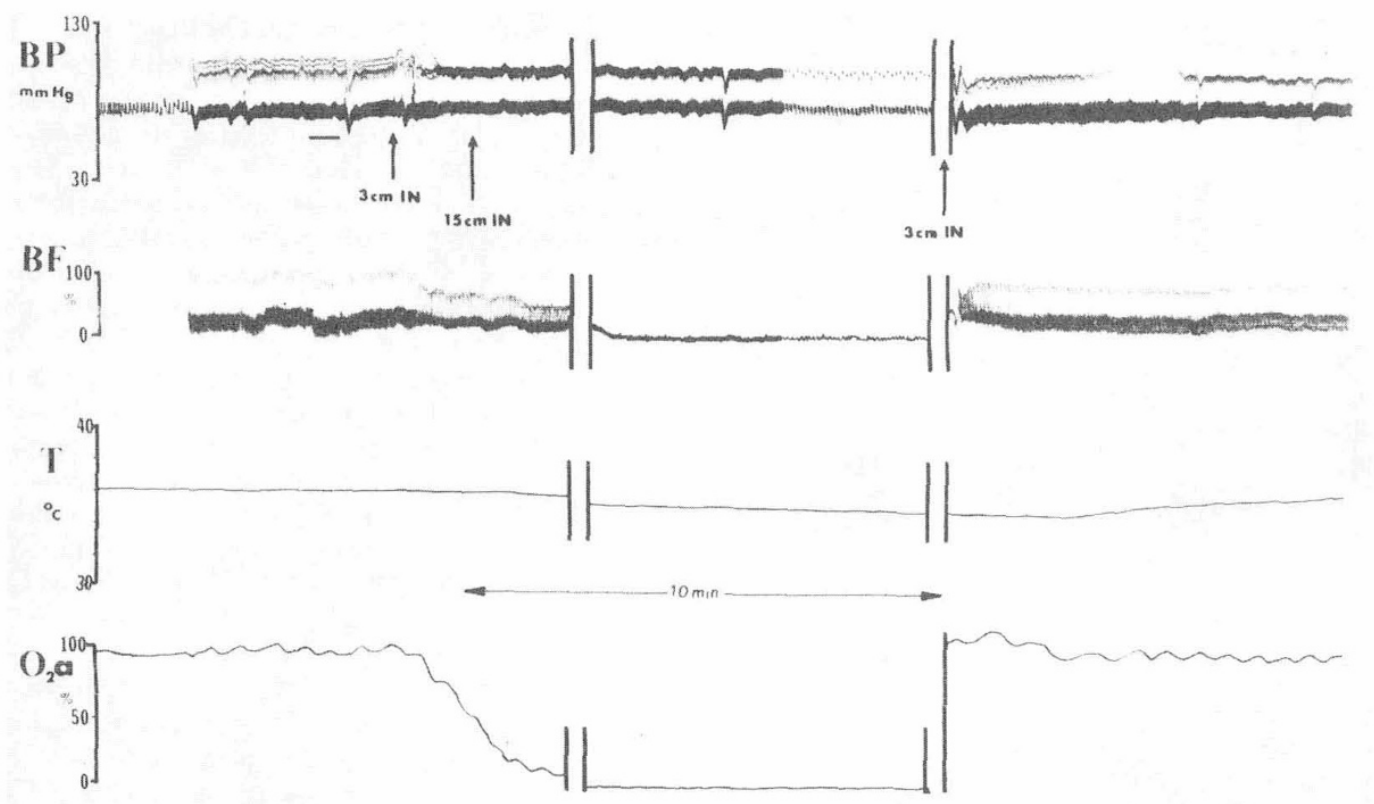

Fig. 3. Changes in blood pressure $(B P)$, right common iliac artery blood flow $(B F)$, gracilis muscle tissue oxygen availability $\left(\mathrm{O}_{2} a\right)$, and extremity temperature $(T)$ produced by advancement of $5.0 \mathrm{~F}$ catheter in a $2.7-\mathrm{kg}$ animal. $3 \mathrm{~cm} I N$ : catheter tip below bifurcation of the aorta; $15 \mathrm{~cm} I N$ : catheter advanced to 15 -cm mark.

$5 \%)$. The difference between these two groups is significant $(p<$ $0.001 ; t=54.531$ ). Only 2 determinations out of II showed any effect on $\mathrm{O}_{2}$ a. BP changed only very slightly and insignificantly in both groups after catheter advancement.

Changes in $\mathrm{O}_{2}$ a as a function of body weight produced by advancement of $3.5 \mathrm{~F}$ and $5.0 \mathrm{~F}$ catheters in animals in which the blood flow probe was not implanted are shown in Figure 4. Advancement of $3.5 \mathrm{~F}$ catheters in animals weighing more than 1.0 $\mathrm{kg}$ did not produce any change in $\mathrm{O}_{2} \mathrm{a}$. In those weighing less than $1.0 \mathrm{~kg}$ but more than $0.7 \mathrm{~kg}$, the gradual decrease was proportional to body weight, whereas in those weighing less than $0.7 \mathrm{~kg}_{2} \mathrm{O}_{2} \mathrm{a}$ reached the zero level. Advancement of $5.0 \mathrm{~F}$ catheters in animals weighing more than $1.6 \mathrm{~kg}$ did not produce any change in $\mathrm{O}_{2} \mathrm{a}$. In those weighing less than $1.6 \mathrm{~kg}$ but more than $1.4 \mathrm{~kg}$, the decrease was again proportional to the body weight, and in those weighing less than $1.4 \mathrm{~kg} \mathrm{O}_{2}$ a was $100 \%$ decreased.

\section{DISCUSSION}

In evaluating the oxygenation of distressed newborns, introduction of catheters into the aorta via an umbilical artery is widely practiced. Possible complications of this procedure are accepted in exchange for data which may protect the brain from hypoxia and the eyes and lungs from hyperoxia. There are logical arguments for placement of the catheter tip at one of two sites: placement at or slightly above the diaphragm assures lack of infusion directly into an aortic branch, whereas placement below the level of aortic bifurcation produces less obstruction due to the shorter length of 
Table 1. Physiologic variables during control and at 5 and 10 min after catheter advancement ${ }^{1}$

\begin{tabular}{|c|c|c|c|c|c|c|c|c|c|c|c|c|c|}
\hline \multirow[b]{2}{*}{$\begin{array}{l}\text { Catheter } \\
\text { size }\end{array}$} & \multirow{2}{*}{$\begin{array}{c}\text { Weight } \\
\text { range, } \\
\mathrm{kg}\end{array}$} & \multicolumn{3}{|c|}{$\mathrm{BP}, \mathrm{mm} \mathrm{Hg}$} & \multicolumn{3}{|c|}{$\mathrm{O}_{2} \mathrm{a}, \%$} & \multicolumn{3}{|c|}{$\mathrm{BF}, \%$} & \multicolumn{3}{|c|}{$\mathrm{T},{ }^{\circ} \mathrm{C}$} \\
\hline & & $\begin{array}{l}\text { Con- } \\
\text { trol }\end{array}$ & $5 \mathrm{~min}$ & $10 \mathrm{~min}$ & $\begin{array}{l}\text { Con- } \\
\text { trol }\end{array}$ & $5 \mathrm{~min}$ & $10 \mathrm{~min}$ & $\begin{array}{l}\text { Con- } \\
\text { trol }\end{array}$ & $5 \mathrm{~min}$ & $10 \mathrm{~min}$ & $\begin{array}{l}\text { Con- } \\
\text { trol }\end{array}$ & $5 \mathrm{~min}$ & $10 \mathrm{~min}$ \\
\hline $3.5 \mathrm{~F}$ & $\begin{array}{l}1.6- \\
2.3\end{array}$ & $\frac{92 \pm 11}{68 \pm 6}$ & $\frac{98 \pm 8}{72 \pm 3}$ & $\frac{98 \pm 8}{72 \pm 3}$ & 100 & $54 \pm 49$ & $56 \pm 50$ & 100 & $68 \pm 43$ & $67 \pm 44$ & $\begin{array}{r}34.7 \\
\pm 0.5\end{array}$ & $\begin{array}{r}34.4 \\
\pm 0.7\end{array}$ & $\begin{array}{r}34.0 \\
\pm 1.1\end{array}$ \\
\hline & $\begin{array}{l}2.6- \\
3.5\end{array}$ & $\frac{115 \pm 11}{84 \pm 9}$ & $\frac{121 \pm 18}{88 \pm 16}$ & $\frac{120 \pm 19}{88 \pm 16}$ & 100 & $83 \pm 35$ & $86 \pm 35$ & 100 & $90 \pm 21$ & $90 \pm 24$ & $\begin{array}{r}38.4 \\
\pm 1.7\end{array}$ & $\begin{array}{r}37.9 \\
\pm 2.3\end{array}$ & $\begin{array}{r}37.7 \\
\pm 2.6\end{array}$ \\
\hline $5.0 \mathrm{~F}$ & $\begin{array}{l}1.6- \\
2.3\end{array}$ & $\frac{109 \pm 7}{74 \pm 3}$ & & $\frac{107 \pm 3}{76 \pm 4}$ & 100 & $24 \pm 20$ & $22 \pm 34$ & 100 & $17 \pm 24$ & $21 \pm 32$ & $\begin{array}{r}36.0 \\
\pm 1.0\end{array}$ & $\begin{array}{r}34.7 \\
\pm 0.1\end{array}$ & $\begin{array}{r}35.0 \\
\pm 0.8\end{array}$ \\
\hline & $\begin{array}{l}2.6- \\
3.5\end{array}$ & $\frac{126 \pm 17}{84 \pm 10}$ & $\frac{138 \pm 6}{87 \pm 3}$ & $\frac{132 \pm 16}{87 \pm 12}$ & 100 & $33 \pm 33$ & $31 \pm 27$ & 100 & $71 \pm 8$ & $73 \pm 6$ & $\begin{array}{r}39.2 \\
\pm 1.2\end{array}$ & $\begin{array}{r}37.6 \\
\pm 0.9\end{array}$ & $\begin{array}{l}37.5 \\
\pm 0.1\end{array}$ \\
\hline
\end{tabular}

${ }^{1}$ BP: arterial blood pressure; BF: common iliac artery blood flow; $\mathrm{O}_{2}$ a: gracilis muscle tissue oxygen availability; $\mathrm{T}$ : subcutaneous temperature.

Table 2. Physiologic variables during control and 10 min after catheter advancement: Blood flow probe was not implanted ${ }^{1}$

\begin{tabular}{|c|c|c|c|c|c|c|c|}
\hline \multirow{2}{*}{$\begin{array}{l}\text { Catheter } \\
\text { size }\end{array}$} & \multirow{2}{*}{$\begin{array}{c}\text { Weight } \\
\text { range, } \\
\text { kg }\end{array}$} & \multicolumn{2}{|c|}{$\mathrm{BP}, \mathrm{mm} \mathrm{Hg}$} & \multicolumn{2}{|c|}{$\mathrm{O}_{2} \mathrm{a}, \%$} & \multicolumn{2}{|c|}{$\mathrm{T},{ }^{\circ} \mathrm{C}$} \\
\hline & & Control & $10 \mathrm{~min}$ & Control & $10 \mathrm{~min}$ & Control & $10 \mathrm{~min}$ \\
\hline & $\begin{array}{l}1.4- \\
2.6\end{array}$ & $\frac{114 \pm 16}{82 \pm 10}$ & $\frac{111 \pm 15}{84 \pm 10}$ & 100 & 100 & $\begin{array}{r}37.6 \\
\pm 1.1\end{array}$ & $\begin{array}{r}37.4 \\
\pm 1.0\end{array}$ \\
\hline $5.0 \mathrm{~F}$ & $\begin{array}{l}0.55- \\
1.55\end{array}$ & $\frac{118 \pm 13}{72 \pm 16}$ & $\frac{117 \pm 27}{81 \pm 23}$ & 100 & $1 \pm 1$ & $\begin{array}{r}36.6 \\
\pm 1.7\end{array}$ & $\begin{array}{r}35.0 \\
\pm 2.1\end{array}$ \\
\hline & $\begin{array}{l}1.6- \\
2.6\end{array}$ & $\frac{126 \pm 17}{76 \pm 12}$ & $\frac{122 \pm 13}{82 \pm 11}$ & 100 & $98 \pm 5$ & $\begin{array}{r}36.9 \\
\pm 1.9\end{array}$ & $\begin{array}{r}37.1 \\
\pm 1.8\end{array}$ \\
\hline
\end{tabular}

${ }^{1}$ BP: arterial blood pressure; $\mathrm{O}_{2}$ a: gracilis muscle tissue oxygen availability; $\mathrm{T}$ : subcutaneous temperature.

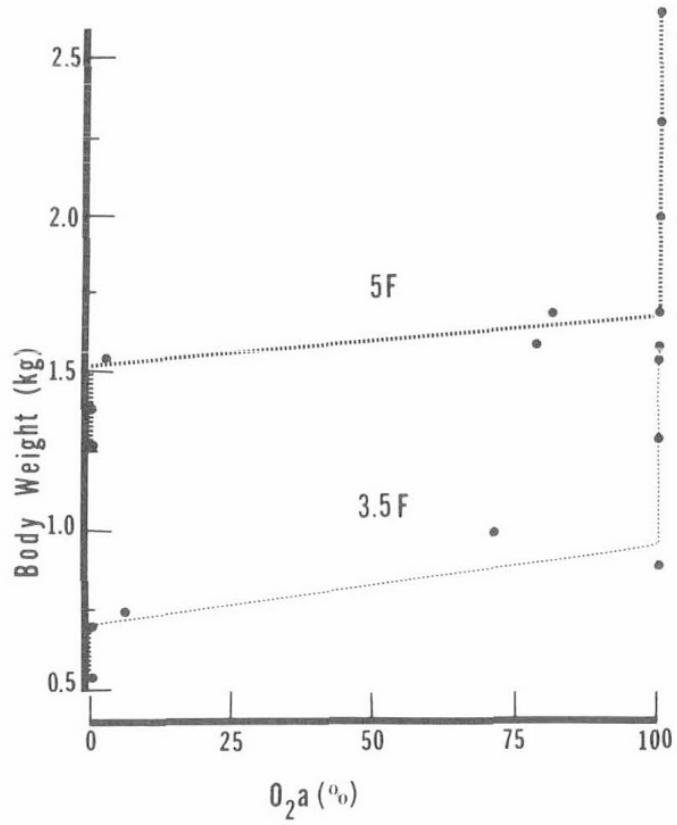

Fig. 4. Changes in gracilis muscle tissue oxygen availability $\left(\mathrm{O}_{2} a\right)$ as a function of body weight produced by $15-20 \mathrm{~cm}$ advancement of $3.5 \mathrm{~F}$ and $5.0 \mathrm{~F}$ catheters. catheter introduced. Two catheter sizes, 3.5 and 5.0 French, have been commonly used.

By calculating the changes in flow when a cylinder is converted to an annular system, we estimated that placement of an aortic catheter could possibly reduce blood flow. As with flow in cylindrical tubes, the radii in an annular system are the variables most significantly influencing flow because they are fourth power variables. These theoretical considerations led us to design experiments for evaluating obstruction to aortic flow produced by indwelling catheters.

The observations were intentionally limited to a maximum 30 -min period in order to eliminate the possibility of further obstruction to blood flow because of thrombus formation. We do recognize, however, that this time limitation might present a problem if the initial decrease in $\mathrm{O}_{2} \mathrm{a}$ is related to vasospasm due to catheter advancement. It is possible that the 30 -min period was not long enough to allow for the relaxation of a possible spasm. Nevertheless, theoretical calculations, the gradual difference in $\mathrm{O}_{2}$ a decrease related to the size of the vessel, and the rather rapid recovery after catheter withdrawal all suggest obstruction rather than vasospasm.

Our results indicate that reduction in $\mathrm{BF}, \mathrm{O}_{2} \mathrm{a}$, and $\mathrm{T}$ is related to the relative dimensions of the vessel and the catheter $(\Delta r)$. In animals weighing less than $1.0 \mathrm{~kg}, 3.5 \mathrm{~F}$ catheters decreased $\mathrm{BF}, \mathrm{T}$, and $\mathrm{O}_{2} \mathrm{a}$, whereas $5.0 \mathrm{~F}$ catheters produced similar decreases in animals weighing less than $1.6 \mathrm{~kg}$. Although the radius of the $3.5 \mathrm{~F}$ catheter is $70 \%$ that of the $5.0 \mathrm{~F}$, the obstructing cross-sectional 
area of the latter is doubled. In addition, the ratio of the catheter's cross-sectional area to the vessel's free flow area increases with the decreasing diameter of the vessels. Both of these account for the impressive difference in flows through the annular space, resulting in a significant reduction in oxygen supply to the extremities. This suggests that only $3.5 \mathrm{~F}$ (or smaller) catheters should be used in small newborns.

The discrepancy in results (Figures 2, 3, and 4 and Tables 1 and 2 ) between the animals in which the blood flow probe was used and the animals without the blood flow probe can be attributed to the initial vasospasm produced by placement of the probe around the vessel. In these animals, a smaller flow obstruction would produce a more pronounced decrease in $\mathrm{BF}$ and $\mathrm{O}_{2} \mathrm{a}$.

Clinically, various sites have been suggested for catheter placement $(1,6,11)$. Our data indicate that there is no change in oxygen supply to the opposite extremity when the catheter is placed below the aortic bifurcation, suggesting that this is a preferred site. This concurs with recent reports by others $(4,10)$. Size and site of a catheter and size of blood vessels should be considered during the clinical application of umbilical artery catheters. Undesirable changes could be detected by continuous monitoring of extremity $\mathrm{O}_{2} \mathrm{a}$ or differential core and extremity $\mathrm{T}$.

\section{SUMMARY}

Placement of catheters in the abdominal aorta produces an obstruction which is manifested by decreased extremity blood flow, muscle oxygen availability, and temperature, and which is greater with $5.0 \mathrm{~F}$ catheters and more pronounced in animals weighing less than $1.6 \mathrm{~kg}$.

Placement of the catheter below the aortic bifurcation did not produce any change in blood flow and oxygenation of the contralateral extremity, suggesting that this is a preferred site. These and other complications could be detected by differential monitoring of extremity and core temperature or extremity tissue oxygen availability.

\section{REFERENCES AND NOTES}

1. Baker, D. H., Berdon, W. E., and James, L. S.: Proper localization of umbilical artery and venous catheters by lateral roentgenograms. Pediatrics, 43: 34 (1969).

2. Beran, A. V., Strauss, J., Brown, C. T., and Katurich, N.: A simple arterial occluder. J. Appl. Physiol. 24: 838 (1968).

3. Beran, A. V., Strauss, J., Sperling, D. R., Norton, A. C., Garwood, V. P., and Yamazaki, J.: Effect of Thalidomide on brain oxygenation. Pediat. Res., 5: 199 (1971).

4. Book, L. S., Herbst, J. J., and Atherton, S.: Gluteal necrosis and gastrointestinal bleeding: Complications of $\mathrm{Ca}$ gluconate infusion through umbilical artery catheterization. Clin. Res., 23: 157 (1975).

5. James, L. S.: Biochemical aspects of asphyxia at birth. In: Adaptation to Extrauterine Life. Report of the 31 st Annual Ross Conference on Pediatric Research, Vancouver, British Columbia, 1959 (Ross Laboratories, Columbus, Ohio, 1959).

6. James, L. S.: Complications arising from catheterization of the umbilical vessels. In: Problems of Neonatal Intensive Care Units. Report of the 59th Ross Conference on Pediatric Research, Stowe, Vermont, 1969 (Ross Laboratories, Columbus, Ohio, 1969).

7. Kitterman, J. A., Phibbs, R. H., and Tooley, W. H.: Catheterization of umbilical vessels in newborn infants. Pediat. Clin. N. Amer., 17: 895 (1970).

8. Lackey, D. A., and Taber, P.: An unusual complication of umbilical artery catheterization. Pediatrics, 49: 281 (1972).

9. Moss, A. J., Adams, F. H., O'Loughlin, B. J., and Dixon, W. J.: The growth of normal aorta and of the anastomotic site in infants following surgical resection of coarctation of the aorta. Circulation, 19: 338 (1952).

10. Powers, W. F., and Swyer, P. R.: Limb blood flow following umbilical arterial catheterization. Pediatrics, 55: 248 (1975).

11. Vidyasagar, D., Downes, J. J., and Boggs, T. R.: Respiratory distress syndrome of newborn infants. II. Technic of catheterization of umbilical artery and clinical results of treatment of 124 patients. Clin. Pediat., 9: 332 (1970).

12. This work was partially supported by the National Institutes of Health, National Heart and Lung Institute Contract N01 5-2947.

13. Requests for reprints should be addressed to: R. F. Huxtable, M.D., Department of Pediatrics, University of California, Irvine, California College of Medicine, Irvine, Calif. 92717 (USA).

14. Accepted for publication January 28, 1976.

\title{
A Comparison of the Active Stiffness of Fetal and Adult Cardiac Muscle
}

\author{
RICHARD A. McPHERSON, MARTHA F. KRAMER, JAMES W. COVELL, AND \\ WILLIAM F. FRIEDMAN ${ }^{19}$ \\ Departments of Pediatrics, Pathology, and Medicine, University of California, San Diego, School of Medicine, \\ La Jolla, California, USA
}

Extract

This report describes the in vitro analysis of the series elasticity of ventricular myocardium isolated from five fetal lambs and six adult sheep. Active compliance measurements were obtained by quick releases utilizing a closed loop servosystem and electromagnetic positioning device to control cardiac muscle length or tension. Right ventricular moderator bands were obtained from five fetuses (average 139 days of gestation, term $=147$ days), and compared with two adult moderator bands and four adult right ventricular trabeculae carneae. After correction for equipment coupling, the experimental load extension data were fit to an exponential expression by a least squares technique: $\operatorname{strain}=1 / b \ln (I+$ stress $/ \mathbf{a})$.

When fetal and adult data were compared, no age-related differences in the constants were observed $(a=0.185 \pm 0.062 \mathrm{SE}$ (fetal) and $0.159 \pm 0.03 \mathrm{~g} / \mathrm{mm}^{2}$ (adult); $\mathrm{b}=\mathbf{4 0 . 4} \pm 5.2$ (fetal) and $43.1 \pm 5.2$ (adult); and $a b=7.39 \pm 2.34$ (fetal) and $5.27 \pm .99$ (adult). However, significant variation existed in the histologically determined amount of contractile tissue present in muscle samples from both fetus $(57-85 \%$, average $=74.0 \pm 4.9)$ and adult 